\title{
The Kazakh Famine of 1930-33: Current Research and New Directions
}

\author{
Sarah Cameron \\ University of Maryland
}

\begin{abstract}
Although the Kazakh famine of 1930-33 led to the death of 1.5 million people, a quarter of Soviet Kazakhstan's population, the crisis is little known in the West. However, in recent years a number of scholars in Europe and the United States have begun to research the issue. This article offers an overview of their scholarship, highlighting points of agreement and debate. But despite this new wave of scholarly interest, several facets of the Kazakh disaster still remain poorly understood. This essay concludes by suggesting areas for future scholarly investigation and research.
\end{abstract}

Keywords: Famine, Kazakhstan, Soviet, Genocide, Nomad

Grom 1930 to 1933, a devastating famine ravaged the new Soviet republic of Kazakhstan. More than 1.5 million people, approximately a quarter of the republic's population at the time, perished in the crisis. The catastrophe, which was sparked by Joseph Stalin's policies of radical state transformation, provoked profound social, demographic, and environmental changes in Soviet Kazakhstan, a territory approximately the size of continental Europe. Its effects continue to be felt in independent Kazakhstan today. Though the Kazakh famine of 1930-33 has important implications for Soviet history, as well as the study of mass violence and comparative famines, the crisis is little known in the West. Most major overviews of the Soviet period refer to the Kazakh disaster only in passing, and the Kazakh famine is rarely mentioned in synthetic accounts of twentieth-century mass violence.

This essay begins with a brief overview of the basic features of the Kazakh famine as they are currently understood by historians. It discusses some of the explanations given for the Kazakh famine at the time, and by later generations of Soviet scholars. It then examines several recent studies of the Kazakh famine by Western scholars. Combined, this new scholarship highlights the violent nature of the Soviet regime's assault on Kazakh society. It has also begun to raise awareness of the issue of the Kazakh famine of 1930-33 among historians writing in the West. But despite this new wave of scholarly interest, several facets of that disaster still remain 
poorly understood. This essay concludes by suggesting a number of areas for future scholarly investigation and research.

\section{The BASIC FEATURES OF THE KAZAKH FAMINE}

The Kazakh famine was a part of the collectivization famines that afflicted the Soviet Union during the years 1930-33, most notably in Ukraine but also in the Volga, Don, and Kuban areas of the Russian Soviet Federated Socialist Republic (SFSR). Each famine was sparked by the same basic cause. In 1929, under Stalin's leadership, the Bolshevik Party launched the First Five-Year Plan, a program to transform society, industry, and agriculture across the new Soviet state. Activists worked to collectivize the countryside, uprooting peasants from their lands and funneling their agricultural products, such as meat and grain, to the state. This assault was particularly brutal, and those regions that had traditionally supplied the food soon began to suffer.

On the eve of the famine, the new Soviet republic of Kazakhstan was a multi-ethnic society composed of a group of Muslim, Turkic-speaking nomads known as "Kazakhs," the republic's majority ethnic group (57.1 percent of the population), and of significant Russian and Ukrainian minorities-19.6 and 13.2 percent respectively (Vsesoiuznaia perepis' 82 ; IX). As nomads, Kazakhs carried out seasonal migrations along pre-defined routes with their animal herds, such as camels, sheep, and horses. They migrated in nomadic encampments known as auls, with each aul consisting of somewhere between two to eight households. This way of life was an adaption to the peculiarities of the Kazakh steppe environment, including the scarcity of good pastureland and water.

The place known as "Kazakhstan" was a product of Soviet rule: In 1924 Moscow began to reorganize the borders of Soviet Central Asia based upon the principle of nationality. It cobbled together territories with distinct cultural, historical, and environmental features, creating what became known as Kazakhstan, or the Kazakh Autonomous Soviet Socialist Republic (ASSR). ${ }^{1}$ Kazakhstan was distinguished both by its size-it was the Soviet Union's second-largest republic, exceeded in size only by the Russian

\footnotetext{
${ }^{1}$ Immediately after the 1924 national delimitation, or reorganization of the political borders of Soviet Central Asia based upon the principle of nationality, this territory was known as the Kyrgyz ASSR. In 1925 it was renamed the Kazakh ASSR. In 1936 Kazakhstan became an SSR with full union-republic status.
} 
SFSR - and by the number of its pastoral nomads, the largest of any republic in the Soviet Union.

Kazakhstan's Slavic peasant population was concentrated heavily in the republic's fertile northern and southeastern regions. Most were relatively recent arrivals, having settled the Kazakh steppe under Russian imperial rule during an intense period of peasant colonization in the late nineteenth and early twentieth centuries. As they brought large swathes of the steppe under cultivation, those settlers transformed the steppe and its economic practices, and these changes, which ranged from shifts in trading patterns to alterations in the Kazakh nomads' migration routes, would later serve to intensify the effects of the Soviet regime's brutal policies. By the early Soviet period, northern Kazakhstan had become one of the Soviet Union's most important grain-producing regions.

During 1929 and 1930, Moscow launched the first collectivization drive. In certain Kazakh regions of the republic, activists began a program of "full collectivization on the basis of sedentarization," a scheme to settle and collectivize nomads simultaneously. Famine began in the winter of 1930, a year earlier than in other parts of the Soviet Union. Though hunger struck Russian and Ukrainian peasant communities in the republic's north and southeast, it hit the nomadic Kazakhs with particular intensity. Nomads began slaughtering their livestock herds for food and fleeing the republic. During the years 1931-33-the height of the Kazakh famine-more than 1.1 million people, the vast majority of them Kazakhs, left the republic. ${ }^{2}$ They fled to neighbouring Soviet republics but also abroad, to the Chinese province of Xinjiang, which bordered Soviet Kazakhstan to the east. Many of these refugees would never return to Kazakhstan, settling in China or in neighbouring Soviet republics permanently. Within Kazakhstan, massive uprisings, some numbering several thousand participants, erupted in the fall of 1929 and throughout the years 1930-33. Red Army troops brutally put down these rebellions.

Stalin and Filipp Goloshchekin, Kazakhstan's leader and Party secretary for much of the famine, corresponded regularly during these crises, and Stalin was aware of the extent of Kazakh suffering. On 17 September 1932, after the republic had endured nearly three years of agony, the Party's Central Committee authorized limited concessions, including the private ownership of animals by nomads and shipments of food aid. In early 1933, Moscow fired Goloshchekin from his position, charged him with committing

2 APRK, f. 141, op. 1, d. 6545, l. 169, republished in Degitaev 292. 
"errors" in his leadership of the republic, and replaced him with an Armenian, Levon Mirzoian. The famine itself, however, continued until 1934, when the republic finally began a slow and painful process of recovery.

While the Kazakh famine of 1930-33 resembles the other Soviet collectivization famines in its broad outlines, it has several distinctive features: In Kazakhstan the famine's primary victims were pastoral nomads rather than peasants. Thus the dynamics of hunger in Kazakhstan were different than in the Soviet Union's west-the flight of starving refugees, for instance, was much greater in the Kazakh famine, as nomads used their knowledge of seasonal migration routes to evade repression-while the societal effects of the famine were arguably even more catastrophic. During the famine some ninety percent of the republic's livestock herds perished, dealing a devastating blow to pastoral nomadic society. ${ }^{3}$ Without their herds, Kazakhs could not nomadize. They had no livelihood or means of acquiring food. Prior to the famine, being Kazakh was closely intertwined with being a nomad. But with the death of their animal herds, most Kazakhs were forced to sedentarize, or take up settled lives-a dramatic reorientation of identity.

Ultimately, through the most violent means, the Kazakh famine created Soviet Kazakhstan, a stable territory with clearly delineated boundaries that was an integral part of the Soviet economic system. But the nature of this state-driven transformation was uneven: neither Kazakhstan nor Kazakhs themselves became integrated into the Soviet system in precisely the ways that Moscow had originally hoped. The costs of this state formation were horrific, both for the regime, which saw a massive drop in the region's agricultural productivity in the post-famine years, and especially for Kazakh society itself, which bore the disproportionate burden of the disaster's death toll. Of its 1.5 million victims, approximately 1.3 million were Kazakhs. More than a third of all Kazakhs perished in the famine, and in the aftermath of the disaster Kazakhs became a minority in their own republic. Through the crisis, Moscow had sought to eradicate preexisting elements of Kazakh identity, such as kinship ties, allegiances to a hereditary elite, and the Kazakh pastoral nomadic way of life, superimposing the category of nationality, "Kazakh," in their place. But

3 A secret police report in October 1932 calculated that animal numbers in the republic had dropped by 90.8 percent in comparison with 1929. In some districts, animal losses were estimated at 99.5 percent. RGASPI f. 108, op. 1, d. 11, 1. 3-4, cited in Danilov, Manning, and Viola 2: 22. 
despite the regime's efforts, many of these pre-existing features of Kazakh identity, such as clans or even nomadism itself (which the regime revived in limited areas of the republic in the post-famine years to build up the republic's livestock reserves), continued to play an important role in Kazakh life after the end of the famine.

\section{THE KAZAKH FAMINE AND WESTERN SCHOLARSHIP}

In the decades after the disaster, the Kazakh famine was little discussed in works published in the Soviet Union. Later generations of Soviet historians, while touting the "victories" of collective farm construction in Kazakhstan, acknowledged "mistakes" and "excesses" in nomadic regions during the years 1930-33, largely blaming Goloshchekin's wrong-headed leadership, the explanation given at the time (Tursunbaev 1957; Tursunbaev, Kazakhskii aul 1967; Dakhshleiger and Nurpeisov). Only in the late 1980s and early 1990s, as the Soviet Union itself began to crumble, did discussion of the Kazakh famine explode into public view. In 1992 a government commission under the auspices of Kazakhstan's president Nursultan Nazarbayev ruled that the Kazakh famine should be considered a genocide, and throughout the 1990s the topic of the Kazakh famine dominated popular and scholarly Russian and Kazakh-language media in Kazakhstan. ${ }^{4}$ Strangely, some of those studies simply repeated the Soviet explanation for the famine, terming it "Goloshchekin's genocide" (Abdairaeiymov; Abylkhozhin, Kozybaev, and Tatimov et al.). Other Kazakhstani scholars, publishing in Russian and in Kazakh, offered rich investigations rooted in the archives of the causes and consequences of the famine (Abylkhozhin; Omarbekov 1994, 1997, 2003).

By the late 1990s, however, there were few scholarly or public inquiries into the disaster, and public attention in Kazakhstan began moving away from the subject of the famine. The reasons for this shift need further study, but they may include official fears that further investigation into the famine would sour Kazakhstan's close relationship with Russia. In May 2012, in a speech at the dedication of a memorial to the famine's victims in Astana, Kazakhstan's capital, Nazarbayev signaled that public discussion of the famine might resume, but in a more limited fashion: He urged Kazakhs to remember the famine but cautioned against the dangers

${ }^{4}$ On the findings of this presidential commission, see Kozybaev 15. 
of "politicizing" the disaster, a reference that evokes efforts to seek reparations for the Ukrainian famine from Russia. ${ }^{5}$

Historians in the West studying the Soviet Union have been slow to catch up to the efforts of their Kazakhstani colleagues. The earliest studies of the Kazakh famine by Western scholars provided useful overviews of the disaster's key events, but they were hampered by the inaccessibility of the Soviet archives. In a 1981 article on the collectivization drive in Kazakhstan, the American scholar Martha Brill Olcott framed the Kazakh famine largely as a miscalculation on the part of Stalin and others, who, she argued, poorly understood the specifics of the Kazakhs' pastoral nomadic economy (Olcott 122-42). In his seminal 1986 work on the Ukrainian famine, The Harvest of Sorrow, the historian Robert Conquest included a chapter on the Kazakh famine, which drew upon Olcott's materials and reached similar conclusions (Conquest 189-98).

In the West study of the Kazakh famine then lay dormant for nearly two decades until an international group of scholars began to revive it. They include the French scholar Isabelle Ohayon, the Italian scholar Niccolò Pianciola, the American scholar Matthew Payne, the German scholar Robert Kindler, and me, an American scholar at the University of Maryland-College Park (Ohayon; Pianciola 2009; Payne 2011; Kindler; Cameron; Mark; and Werth). ${ }^{6}$ These scholars benefitted from the opening of the Soviet state and Party archives after the fall of the Soviet Union in 1991. More recently, the President's Archive of the Republic of Kazakhstan, which holds records pertaining to the activities of Soviet Kazakhstan's Communist Party, has released the records of important Party control commissions and inspectorate commissions that operated during the famine. ${ }^{7}$ Under President Nazarbayev's program of limited public discussion of the famine, Kazakhstan's Ministry of Culture has begun work on a useful multi-volume document collection devoted to the Kazakh famine, the first volume of which has been released, which compiles archival documents from state, Party, and regional archives (Zulkasheva).

${ }^{5}$ Nazarbayev noted: "But we should be wise in interpreting history and not allow the politicization of this theme" ("Vystuplenie" 9).

${ }^{6}$ Pianciola 2004 includes many of his conclusions in English.

7 At the Presidential Archives, these are the Peoples' Commissariat of the WorkerPeasant Inspectorate (collection 719) and the Authorized Commission of Party Control (collection 725), as well as the "secret" opis (subdivision), of the regional Party Committee (collection 141, opis 17). 
By no means have all of the archival records relating to the famine become available. For example, Kazakhstan's secret police archives and the personal files of certain key individuals, such as Goloshchekin, remain closed to both foreign researchers and most local researchers. ${ }^{8}$ But this new wave of foreign scholars has utilized the rich records that are available to make a number of key interventions in the scholarly literature. Their combined research illustrates the violent nature of the regime's assault on Kazakh society. Rather than framing Stalin as unaware of the disaster, their scholarship has revealed that Stalin knew of the Kazakhs' suffering at several key points in the famine yet offered no concessions.

These findings puncture the long-standing misconception that the Kazakh famine was primarily a "natural" process, one that was distinct from the more brutal path that collectivization took elsewhere in the Soviet Union. This notion still lingers in the scholarly literature: The Kazakh disaster is often dismissed as Moscow's "mistake" or "miscalculation, depictions that would seem to downplay the disaster's violent nature. ${ }^{9}$ In part, such portrayals evoke the ideas of evolutionary theorists, who argue that the disappearance of mobile peoples and their transformation into settled societies are an inevitable outgrowth of modernity. A number of scholars working outside the field of Soviet history have successfully challenged the conclusions of evolutionary theory, but it has clouded interpretations of the Kazakh famine. ${ }^{10}$ Arguably, the sense or the implication that the Kazakh famine was not really an act of terror at all may be one of the reasons that the topic has been neglected for so long by scholars in the West. If this is understood as a historical problem that originated largely from natural causes, then it is understandable that historians should first turn their attention to unearthing those Soviet crimes that stemmed from human causes.

It is worth noting the differences of interpretation and emphasis within this group of five foreign scholars. One area of disagreement is when the story of the Kazakh famine begins and ends. For Pianciola (2009, 33-87) the story of the famine begins in the 1890s, when peasant settlement of the

8 The historian Talas Omarbekov has utilized files in Kazakhstan's secret police archives. See Omarbekov 2003.

${ }^{9}$ Conquest, for instance, argues that the Kazakh disaster was due to economic and political miscalculation, but was even more profoundly "a misunderstanding of cultures in the widest meaning of the term" (194).

10 Both Kasaba and Scott have recently challenged evolutionary approaches to understanding the relationship between agrarian and non-agrarian peoples. 
Kazakh steppe accelerated. Kindler, by contrast, places less emphasis on the legacies of Russian imperial rule and begins his book in 1921, soon after the end of the civil war. ${ }^{11}$ Pianciola largely ends his narrative in 1934, when the famine itself came to an end, while Kindler and Ohayon extend their narratives until 1945. They reveal, for instance, that in limited areas of the republic, Moscow revived pastoral nomadism, the very way of life that the regime had once sought to eradicate, in an effort to restore the republic's livestock numbers to their pre-famine levels (Kindler 312-38; Ohayon 32755).

These differences in chronology point to larger issues. Just how important was the legacy of Russian imperial rule to the nature of the Kazakh disaster? Would a similar famine have occurred in the 1930s without peasant settlement of the Kazakh steppe during the late nineteenth and early twentieth centuries? Ultimately, what did the famine mean for Moscow? How did the disaster's unexpected consequences, such as the massive loss of livestock, change Moscow's approach to ruling the republic? The answers to these questions are crucial to the larger field of Soviet history, as they help us identify continuities and discontinuities between Russian imperial and Soviet rule and clarify the particular nature of the Stalin's transformation of Soviet society.

These historians deploy different lenses and interpretive frameworks to analyze the crisis. Ohayon uses the tools of social history to explore the story of the famine, focusing on the politics of sedentarization as a program of social transformation rather than on central decision-making. Pianciola relies on the methods of economic history to reveal the complex economic interrelationships that bound nomads and peasant settlers. For Kindler the story of the famine is largely one of violence, and he devotes considerable attention to central and local-level patterns of violence. In my forthcoming book, I utilize environmental history, among other approaches, to scrutinize how changing understandings of linkages between the environment and human activity influenced Moscow's approach to developing the region. As these divergent approaches reveal, a famine is a complex human crisis, the study of which requires a range of methodologies, including social, political, economic, and environmental history, to unearth its full dimensions.

These scholars have also debated key questions related to the Soviet regime's intentions in Kazakhstan as well as the course of hunger itself.

11 Kindler includes an eleven-page (31-42) overview of "Nomads and Russian Colonial Power," but his narrative begins with 1921. 
Though there is a general consensus that Stalin's first Five-Year Plan was the spark for the Kazakh crisis, these scholars disagree about how the plan's various elements sparked hunger. In Kazakhstan, efforts to collectivize nomads were accompanied by efforts to sedentarize them permanently and extract grain and meat procurements that would be funneled to the state. Payne stresses the destructive nature of forced sedentarization, while Pianciola emphasizes the role of the grain procurements in sparking hunger. All of these scholars agree that Moscow sought to use famine as a means of bringing Kazakhs under Soviet rule. Pianciola labels this process "etatization," while Kindler calls it "Sovietization through hunger." But they disagree over the extent to which Moscow anticipated the full dimensions of the crisis (Pianciola 2004, 191; Kindler 12). Of these five scholars, only Payne (in "Soviet Steppe") has argued that the Kazakh famine should be considered a genocide, while the others have argued, using various definitions and rationales, that the Kazakh famine should not be considered a genocide. ${ }^{12}$

\section{FUTURE DIRECTIONS FOR RESEARCH}

Although this new wave of foreign scholarship on the Kazakh famine has done much to elucidate the nature of the Kazakh crisis, there are several areas of the disaster that remain under-researched. ${ }^{13}$ First, we do not yet have a clear understanding of the Kazakh famine in its broader, pan-Soviet context. The essays in this journal are a valuable step in thinking about Soviet famines comparatively, but future researchers must also scrutinize the connections that these disasters may have had to one another. What relationship, if any, did the Kazakh famine, which began in the fall of 1930, have to the collectivization famines, including the Ukrainian famine and famine in the Volga, Don, and Kuban areas of Russia, which followed in its wake? Did Moscow's reaction to the Kazakh crisis affect its response to

12 For arguments that the Kazakh famine should not be considered a genocide, see Kindler 27 and Ohayon 360. Pianciola $(2004,190)$ does not address the question of genocide directly but argues that Moscow did not plan the slaughter of Kazakhs. I have argued that the Kazakh famine does not fit the legal definition of genocide as adopted by the United Nations General Assembly, but it may fit broader definitions of genocide (Cameron 21).

13 The list that follows is by no means definitive. As was mentioned earlier in the essay, the particular way that the Kazakh famine has been remembered and memorialized in Kazakhstan is another understudied area of research. 
subsequent food crises? Did the Kazakh crisis embolden Stalin, as some scholars have suggested, providing a "useful model" for his assault on Ukraine? ${ }^{14}$

To date, much of the research on the Soviet collectivization famines has followed national lines, with research on the Ukrainian famine and on the Kazakh famine entirely distinct from one another. ${ }^{15}$ Yet this neglects the broader pan-Soviet context of which both crises were a part: Moscow sought to construct a Union-wide food system, and shortages in one region of the Soviet Union had implications for others. Preliminary research reveals that brutal tactics, such as the closure of borders so that the starving could not flee, may have been developed in response to one famine and then deployed in another (Cameron 18). Consideration of the Kazakh famine in its pan-Soviet context may also help scholars understand why some regions of the Soviet Union did not suffer severe famine during collectivization. We know, for instance, that officials in Soviet Kyrgyzstan, which was inundated with starving Kazakh refugees by 1932, cited the example of the Kazakh famine in efforts to convince Moscow to lower the grain procurements levied on Kyrgyzstan (Loring 350). Further research is needed to ascertain the ways that the Kazakh crisis influenced Moscow's development of Central Asia.

Another understudied area of research is the death toll in the Kazakh famine. Like other Soviet collectivization famines, the mortality figures for Kazakhstan are contested: Most Western scholars estimate that the Kazakh famine claimed the lives of approximately 1.5 million people, the vast majority of whom were ethnic Kazakhs. ${ }^{16}$ Some Kazakhstani scholars

14 Conquest notes: "Nevertheless, it has been suggested that the effectiveness of the unplanned Kazakh famine in destroying local resistance was a useful model for Stalin when it came to the Ukraine" (196). Analyzing Stalin's intentions immediately prior to the Ukrainian famine, the historian Timothy Snyder writes: "By summer 1932, as Stalin knew, more than a million people had already starved to death in Soviet Kazakhstan. Stalin blamed the local Party leader [Filipp] Goloshchekin, but he must have understood some of the structural issues" (35).

15 There are of course exceptions, but most precede this new wave of research on the Kazakh famine. In their book Davies and Wheatcroft engage with articles by Pianciola; other studies on the Kazakh famine had not yet been published at the time that they wrote their book.

16 Maksudov (770) argues that 1.45 million ethnic Kazakhs and 100,000 people of other ethnicities perished. Davies and Wheatcroft (412) estimate that 1.3 to 1.5 million people died in Kazakhstan. Olcott suggests that 1.5 million ethnic Kazakhs died. 
propose higher figures, such as 2.5 million ethnic Kazakh deaths (Tatimov and Aliev 216). Overall the mortality figures for Kazakhstan have been subject to less scrutiny than those for Ukraine or Russia's Volga, Don, and Kuban regions. In 2013 the economic historian Stephen Wheatcroft, then at Nazarbayev University in Astana, began a promising project that proposed to collect data on various famine indicators (such as births, deaths, migration, and procurement levels) from largely unutilized sources, including republic-level and regional-level statistical archives. Using this data and techniques such as historical geographic information systems (GIS) or electronic mapping, Wheatcroft and his team planned to calculate mortality in the Kazakh famine with a far greater degree of precision than previous studies. Such a study would also help researchers identify and analyze regional differences in mortality rates, a subject of particular importance given Kazakhstan's immense size. Unfortunately, Wheatcroft has now left Nazarbayev University, and the status of the project remains uncertain. ${ }^{17}$

There are particular challenges to further investigations into the mortality figures for the Kazakh famine. The flight of starving refugees, for instance, was far more extensive than in other Soviet collectivization famines. During preparations for the 1937 census, some officials in Kazakhstan even used this refugee flight as a way of covering up the famine's existence. The republic's precipitous population drop, they reasoned, could be explained by the fact that so many Kazakhs had emigrated to work in other republics during the period of Stalin's first FiveYear Plan (Hirsch 282). It is clear that this explanation does not hold. By any accepted scholarly measure, the death toll in the Kazakh famine was horrifying. An accurate assessment hinges upon detailed work with population data in other Soviet republics, as well as in Xinjiang. This work will include an accounting of the famine refugees who fled and settled elsewhere permanently and those who perished along the way or the places where they fled.

Further work with this statistical data may also help answer a related question: was starvation or disease the major cause of death in the Kazakh famine? ${ }^{18}$ Typically, in "modern famines" such as the siege of Leningrad, disease does not play a major role-most victims die of actual starvation.

17 Several scholars working on the Kazakh famine, including Kindler, Pianciola, and me, were consultants to the Wheatcroft project.

18 I thank Cormac Ó Gráda for bringing this important point to my attention during a conference on comparative famines at Nazarbayev University in October 2013. 
Disease does not appear to have been a major factor in the Ukrainian famine or in the famines that afflicted the Volga, Don, or Kuban regions. But there were far fewer public health services in Kazakhstan than in the Soviet Union's west, and archival evidence indicates that diseases such as typhus, smallpox, and cholera greatly intensified the death toll. In some cases, Party bureaucrats could not even travel to the most famine-stricken regions of the republic because the outbreak of massive epidemics made such trips too dangerous (Cameron 281). In the Kazakh famine, as in other famines, these diseases were induced by hunger and exacerbated by other faminerelated phenomena, such as massive population movement and unsanitary conditions.19 ${ }^{19}$ Identifying the particular role that disease played in the Kazakh disaster may also help clarify other questions, such as why it took Moscow so long-nearly three years-to bring the Kazakh famine to an end.

Yet another underexplored area is the role of Kazakh actors. How did they understand this assault on their society? And how did the disaster reshape what it meant to be Kazakh? Despite the Party's efforts to promote the use of the Kazakh language, Russian remained the preferred language of communication at the republic, oblast, and raion levels of Kazakhstan's multi-ethnic bureaucracy during the 1920s and 1930s. Thus the vast majority of the primary sources on the Kazakh famine, including most Party and state documents contained in the archives, are in Russian. But within Kazakh society itself the number of Russian speakers remained quite small, and this group tended to come from a sector of Kazakh society that had been educated in so-called "Russian-native" schools. Kazakh remained the major language of communication for the steppe's nomads. In the early twentieth century Kazakh elites had created the first standardized written form of the Kazakh language, which relied on a modified Arabic script. Though literacy rates in Kazakh society remained low through the 1920s, there is a small but significant number of Kazakh-language primary sources from this period, such as petitions, newspapers, and the minutes of meetings of aul, or local-level, soviets. Frequently these sources contain perspectives and voices that cannot be found in Russian-language documents. Few outsiders read Kazakh, and it was a language in which many Kazakhs felt that they could communicate more openly.

Researchers have begun to mine these valuable sources for insights into the ways that Kazakh society was reconstituted during the famine, but

${ }^{19}$ On the linkage between disease and famine, see Sen 50; and Ó Gráda 108-28. 
challenges remain: During the late 1920s Moscow began a campaign to shift native languages such as Kazakh from the Arabic to the Latinate script. In the 1930s Moscow changed the script again, to a modified Cyrillic script, which is still in use in Kazakhstan today. The older Arabic script is very difficult to learn, even for native speakers of Kazakh, and few scholarly studies of the famine period have utilized Kazakh sources written in the Arabic script. ${ }^{20}$ To clarify our understanding of Kazakh society on the eve of the famine, future researchers must take up the daunting challenge of these sources.

The issue of sources raises another challenge particular to the Kazakh famine (in contrast to the Ukrainian famine and the famines in the Volga, Don, and Kuban regions). Because Kazakh culture was largely an oral rather than literary culture, there are very few primary sources that the Party or the state did not produce. Few foreign travellers visited Kazakhstan during the 1920s and 1930s, and there are only a handful of diaries or memoirs about the period. ${ }^{21}$ In Ukraine the Welsh journalist Gareth Jones first brought the horrors of the Ukrainian famine to the attention of the West, and his observations remain an important insight into the human side of the story of the famine (Gamache). In Kazakhstan there was no similar figure to chronicle the story. Oral-history projects on the Kazakh famine began relatively late, and because the famine survivors who were interviewed were generally quite elderly and had been small children during the disaster, these sources are of limited utility for historians. ${ }^{22}$ To capture the human side of the story, researchers must seek out new sources. One potential avenue of investigation may be Kazakh-language literature. While it was not permitted to talk about the famine in official sources for most of the Soviet era, preliminary research in Kazakh-language literary journals from the time period, such as Zhŭldiz, indicates that Kazakh authors often wove the story of the famine into their novels and short stories. These literary sources may yield important insights into topics such as the reconstitution of Kazakh society in the wake of the disaster and the particular ways that Kazakhs remembered the famine during the Soviet era.

20 Makhat is an exception.

${ }^{21}$ Most of these memoirs were written after the Soviet collapse, and arguably they are as much about Kazakhstan's own nation-building efforts as they are about the story of the famine. See Shayakhmetov.

22 See, for instance, the efforts to collect oral histories in 2008 detailed in Tragediia Kazakhskogo naroda. 
Works Cited

Abdairaeiymov, S. Golod v Kazakhskoi stepi: Pisma trevogi i boli. Almaty: Qazaq universiteti, 1991. Print.

Abylkhozhin, Zhuldyzbek B. Traditsionnaia struktura Kazakhstana: sotsialnoekonomicheskie aspekti funktsionirovaniia i transformatsii. Almaty: Gylym, 1991. Print.

Abylkhozhin, Zhuldyzbek B., Manash Kozybaev, and Makash B. Tatimov. "Kazakhstanskaia tragediia." Voprosy istorii 7 (1989): 53-71. Print.

Cameron, Sarah. "The Hungry Steppe: Soviet Kazakhstan and the Kazakh Famine, 1921-1934.” Ph.D. diss., Yale University, 2010. Print.

Conquest, Robert. The Harvest of Sorrow: Soviet Collectivization and the Terror Famine. New York: Oxford University Press, 1986. Print.

Dakhshleiger, G. F. and K. Nurpeisov. Istoriia krest'ianstva Sovetskogo Kazakhstana. Almaty: Nauka, 1985. Print.

Danilov, Victor, Roberta Manning, and Lynne Viola, eds. Tragediia Sovetskoi derevni: Kollektivizatsiia $i$ raskulachivanie: Dokumenty $i$ materialy. Moscow: ROSSPEN, 2001. Print.

Davies, Robert W., and Stephen G. Wheatcroft. The Years of Hunger: Soviet Agriculture, 1931-1933. New York: Palgrave Macmillan, 2004. Print.

Degitaev, L. D., ed. Levon Mirzoian v Kazakhstane: Sbornik dokumentov $i$ materialov (1933-1938 gg.). Almaty: Qazaqstan, 2001. Print.

Gamache, Ray. Gareth Jones: Eyewitness to the Holodomor. Cardiff: Welsh Academic Press, 2013. Print.

Hirsch, Francine. Empire of Nations: Ethnographic Knowledge and the Making of the Soviet Union. Ithaca: Cornell University Press, 2005. Print.

Kasaba, Reşat. A Moveable Empire: Ottoman Nomads, Migrants and Refugees. Seattle: University of Washington Press, 2009. Print.

Kindler, Robert. Stalins Nomaden: Herrschaft und Hunger in Kasachstan. Hamburg: Hamburger Edition, 2014. Print.

Kozybaev, M. K., et al, eds. Nasil'stvennaia kollektivizatsiia $i$ golod $v$ Kazakhstane 1931-33 gg.: Sbornik dokumentov i materialov. Almaty: Fond "XXI vek," 1998. Print.

Loring, Benjamin. "Building Socialism in Kyrgyzstan: Nation-Making, Rural Development, and Social Change, 1921-1932." Ph.D. diss. Brandeis University, 2008. Print.

Makhat, D. A. Baspasöz: Stalinshǐldǐktĭng Qazaqstanda ornïghülï (1925-1956 zh.zh.). Astana: Sozdk-Slovar, 2007. Print.

Maksudov, S. "Migratsii v SSSR v 1932-1939 godakh." Cahiers du Monde russe 40.4 (1999): 763-96. Print.

Mark, Rudolf A. "Die Hungersnot in Kazachstan: Historiographische Aufarbeitung im Wandel.” Osteuropa 54.12 (2004): 112-30. Print. 
Ó Gráda, Cormac. Famine: A Short History. Princeton: Princeton University Press, 2008. Print.

Ohayon, Isabelle. La sédentarisation des Kazakhs dans l'URSS de Staline: Collectivisation et changement social (1928-1945). Paris: Maisonneuve \& Larose-Institut Français d'Études sur l'Asie Centrale, 2006. Print.

Olcott, Martha Brill. "The Collectivization Drive in Kazakhstan." Russian Review 40.2 (1981): 122-42. Print.

Omarbekov, Talas. 20-30 zhïldardaghï Qasaqstan qašrreť̆. Almaty: Sanat, 1997. Print.

---. Qazaqstan tarikhïnïng XX ghasïrdaghï özektĭ mäcelelerĭ. Kömekshĭoqu qŭralï. Almaty: Öner, 2003. Print.

---. Zobalang (küshtep ŭzhumdastïrugha karsïlïq): Oqu qŭralï. Almaty: Sanat, 1994. Print.

Payne, Matthew J. "Seeing like a Soviet State: Settlement of Nomadic Kazakhs, 1928-1934." Writing the Stalin Era: Sheila Fitzpatrick and Soviet Historiography. Ed. Golfo Alexopoulous, Julie Hessler, and Kiril Tomoff. New York: Palgrave Macmillan, 2011. 59-86. Print.

---. "Soviet Steppe: Modernization and Genocide in Kazakhstan, 1916 to 1941." Web. 10 July 2015. http://history.emory.edu/home/people/faculty/paynematthew.html.

Pianciola, Niccolò. "Famine in the Steppe: The Collectivization of Agriculture and the Kazak Herdsmen, 1928-1934." Cahiers du Monde russe 45.1-2 (2004):137-92. Print.

---. Stalinismo di frontiera: Colonizzazione agricola, sterminio dei nomadi e costruzione statale in Asia centrale, 1905-1936. Rome: Viella, 2009. Print.

Scott, James. The Art of Not Being Governed: An Anarchist History of Upland Southeast Asia. New Haven: Yale UP, 2009. Print.

Sen, Amartya. Poverty and Famines: An Essay on Entitlement and Deprivation. Oxford: Oxford UP, 1981. Print.

Shayakhmetov, Mukhamet. The Silent Steppe: The Story of a Kazakh Nomad under Stalin. Trans. Jan Butler. London: Overlook Press, 2006. Print.

Snyder, Timothy. Bloodlands: Europe between Hitler and Stalin. New York: Basic Books, 2010. Print.

Tatimov, Makhash, and Zh. Aliev. Derbesť̌mŭz-demografiiada. Almaty: Zhetı̌ zhaghï, 1999. Print.

Tragediia Kazakhskogo naroda (sbornik dokumentov i materialov golod 20-kh, 30-kh godov XX veka v Kazakhstane). Almaty: Almatï oblïstïq mŭraghatï, 2010. Print.

Tursunbaev, Abde B. Kazakhskii aul $v$ trekh revoliutsiiakh. Almaty: Kazakhstan, 1967. Print.

---. Kollektivizatsiia sel'skogo khoziaistva Kazakhstana 1926-1941 gg. Almaty: Kazakhstan, 1967. Print. 
---. Pobeda kolkhoznogo stroia $v$ Kazakhstane. Almaty: Khazakhskoe gosudarstvgennoe izdatel'stvo, 1957. Print.

Vsesoiuznaia perepis' naseleniia 17 dekabria 1926 g.: Kratkie svodki. Narodnost' i rodnoi iazyk naseleniia SSSR. Moscow: Izdanie TsSU SSSR, 1927. Print.

"Vystuplenie Prezidenta Respubliki Kazakhstan N. A. Nazarbaeva na otkrytii monumenta pamiati zhertv goloda 1932-1933 godov." Sbornik materialov Mezhdunarodnoi nauchnoi konferentsii "Golod v Kazakhstane: Tragediia naroda $i$ uroki istorii." Ed. B. G. Aiagana. Astana: Memleket tarikhy instituty, 2012. Print.

Werth, Nicolas. "La Famine au Kazakhstan, 1931-1933: Le rapport à Staline du 9 mars 1933." Communisme 74-75 (2003): 9-41. Print.

Zulkasheva, A. S. Tragediia Kazakhskogo aula, 1928-1934: Vol. 1. 1928-aprel' 1929. Almaty: Raritet, 2013. Print. 